Stormy., dkk, Isolation of... 1659

\title{
ISOLATION OF SIX MARINE ACTINOMYCETES FROM MANGROVE SEDIMENT OF OESAPA BEACH AND SCREENING FOR HYDROLYTIC EXOENZYMES AS FEED ADDITIVES
}

\author{
Stormy Vertygo'), Basry Yadi Tang(2), Geti Pahnael1), Suhartini Salih"1) \\ 1) Department of Animal Husbandry, State Agricultural Polytechnic of Kupang \\ 2) Department of Dryland Agriculture Management, \\ State Agricultural Polytechnic of Kupang \\ J. Prof. Dr. Herman Yohanes Lasiana Kupang P.O.Box. 1152, Kupang 85011 \\ Correspondent: svertygo91@gmail.com
}

\begin{abstract}
ABSTRAK
Actinomycetes merupakan kelompok bakteri berfilamen yang bersifat Gram-positif dan paling banyak terdapat di dalam tanah. Bakteri ini menghasilkan berbagai senyawa metabolit sekunder yang secara ekonomis sangat penting seperti antibiotik dan eksoenzim hidrolitik. Isolat Actinomycetes Laut telah berhasil diisolasi dari sedimen tanah hutan Mangrove di daerah pantai Oesapa, Kupang, Nusa Tenggara Timur. Metode isolasi dilakukan melalui pengenceran bertingkat sampel sedimen yang kemudian diinokulasi secara spread plate pada media Sabouraud Agar (SDA). Koloni yang tumbuh kemudian dipurifikasi secara streak plate dan dilanjutkan dengan uji aktivitas eksoenzim hidrolitik: Amilase, Selulase, Protease dan Lipase. Hasil uji memperoleh 6 isolat Actinomycetes yang memiliki aktivitas katalik untuk minimal empat enzim tersebut. Enzim-enzim ini dapat diarahkan pemanfaatannya dalam bidang teknologi pakan ternak khususnya sebagai imbuhan pakan yang umumnya diformulasi dalam pakan ternak untuk meningkatkan kecernaannya dalam tubuh hewan ternak. Hasil penelitian ini juga dapat semakin mengoptimalkan pemanfaatan sumber daya alam lokal khususnya dalam mendukung bidang peternakan pada skala regional.
\end{abstract}

Kata Kunci: Actinomycetes Laut, Sedimen, Pantai Mangrove, Eksoenzim Hidrolitik

\section{INTRODUCTION}

East Nusa Tenggara (ENT) is one of the archipelagic provinces where most of the population are farmers and ranchers (BPS Provinsi ENT, 2020). The area of ENT which is dominated by grasslands, also increasingly supports the development of this livelihood (Sutomo, 2016). Theoretically, this condition is able to support the Ministry of Agriculture's program for the next five years in terms of developing strategic commodities through increasing the production of main commodities, one of which is livestock commodities. This also got a positive sentiment from the Governor of ENT in the $7^{\text {th }}$ Annual National Seminar held by 
the Faculty of Agriculture UNDANA Kupang that ENT is ready to support increasing livestock productivity (Abay, 2020). However, the reality found in the field shows that farmers are still experiencing problems with the availability of feed so that it needs to be imported from outside the region. This problem is mainly sourced from the productivity of agricultural land for feed plants and also the processing technology to produce quality types of feed. Annually recorded around Rp. 1.1 Trillion of funds spent to bring in animal feed from outside the region. To be able to support the Ministry of Agriculture program, one of the efforts planned by the ENT Provincial government is to build its own animal feed factory (Lewokeda, 2020).

Feed additives is often added to animal feed which function to enhance or increase animal welfare including its health, growth, reproduction, as well as productivity (Watts et al., 2020). Enzymes added to animal feed will function to hydrolyze polymer compounds that are difficult for animals to digest into simple monomer compounds, thereby increasing the availability of these nutrients to be absorbed by the digestive organs (Singh, 2015). Enzymes that have this hydrolytic ability are secreted for use outside the cell, so they are also called hydrolytic exoenzymes (Lehmann, 2001). Hydrolytic exoenzymes used in animal feed formulations can come from various sources, especially from microorganisms in terrestrial ecosystems, but they are still very rarely developed from microorganisms in marine ecosystems (Birolli et al., 2019). Currently, many studies have found that certain bacteria called Actinomycetes isolated from the sea can also produce various kinds of hydrolytic exoenzymes that have high commercial value, so they are widely applied in the food industry (Vaijayanthi et al., 2016). However, the prospect of being used as an animal feed additive is still one aspect that is rarely studied.

Therefore, the present study was design to evaluate Actinomycetes bacteria isolated from marine sediments of the Oesapa coastal Mangrove Forest and its potential to produce hydrolytic enzymes as animal feed additives. Types of hydrolytic enzyme analyzed in this research were: amylase, cellulase, protease, and lipase. Results from this research is expected to help reduce the costs required in providing imported feed by using feed additives from their own regions. In addition, it can also support the construction of animal feed factories through the 
use of feed additives in the form of hydrolytic exoenzymes from alternative local resources to produce high-quality animal feed.

\section{METHOD}

\section{Study area and Location of Sampling Site}

This research was carried from June - September 2021 and mainly conducted at the Animal Feed Technology laboratory, State Agricultural Polytechnic of Kupang. Sediment of Mangrove Forest was taken aseptically from one location site at the coastal area of Oesapa Beach, Kupang, East Nusa Tenggara. The sediments were kept inside at a sterile plastic bag soaked with $\mathrm{NaCl}$ $0,9 \%$ solution.

\section{Isolation \& Purification}

The sediments were then suspended in sterilized water for 1 gram in $9 \mathrm{~mL}$ of $\mathrm{H}_{2} \mathrm{O}$ and continued to 5 -fold dilutions (10-5). As much as $0,1 \mathrm{~mL}$ from $10^{-4}$ and $10^{-5}$ suspensions was inoculated in Sabouraud Dextrose Agar (SDA) by using spread plated method with 2 repetitions for each dilution. The medias were incubated at room temperature for 7 days (Aghamirian \& Ghiasian, 2009; Dharma Rudiansyah Rahmawati, 2019). Colonies appeared were selected for Actinomycetes bacteria which was characterized by having a powdery texture, earthy smell, filamentous growth pattern and could often produce pigments (Joseph et al., 2021; Ortenberg $\&$ Telsch, 2003). Each Actinomycetes colony was streaked on the same media (SDA) until purified isolates were obtained.

\section{Screening for Hydrolytic Exoenzymes}

Screening for hydrolytic exoenzymes was conducted for four enzymes which were: Amylase, Cellulase, Protease and Lipase. These enzymes are the ones commonly applied as feed additives (Velázquez-De Lucio et al., 2021). The basic media used was ISP2 agar. For Amylase activity, pure culture of Marine Actinomycetes was inoculated in ISP2 agar $+1 \%$ amylum. After incubation, the media was poured with $1 \%$ of iodine solution. Positive result would show no colour on the media, while negative result would show blue colour around the colony 
(Luang-In et al., 2019).

For cellulase activity, the isolates were inoculated on ISP2 agar $+1 \%$ of Carboxy Methyl Cellulose (CMC). Colony appeared on the media were then soaked with $0,1 \%$ of Congo-Red solution for 15 minutes. It was later soaked with $\mathrm{NaCl} 1 \mathrm{M}$ for 15 minutes and rinsed three times. Clear zone formed around the colony would indicate positive result of containing cellulase enzyme (Gohel et al., 2014).

Lipase activity was screened by inoculating each isolated in ISP2 agar $+1 \%$ olive oil $+0,1 \%$ Rhodamin-B. The media would have a reddish colour and positive result would appear as colourless and the colony would turn into reddish in colour as it absorbs the Rhodamine-B dye (Pramiadi \& Yulianti, 2014).

Protease activity was identified by any clear zones formed around the colony grown on ISP2 agar + 1\% skim milk. All the media above used the same incubation period which were room temperature for 3 days (Alnahdi, 2012).

\section{RESULTS AND DISCUSSION}

Isolation was conducted by using spread plate method as this group of bacteria is mainly aerobic. This technique resulted in 14 isolates, and 6 of them were determined as Actinomycetes colonies from Mangrove sediment based on its characterization. Actinomycetes colonies are characterized by having leathery texture, filamentous growth pattern, having a 'earthy-like' smell and could sometimes display pigmentation. Purification of theses 6 isolates was done 2 times to obtain a pure culture of each colony.

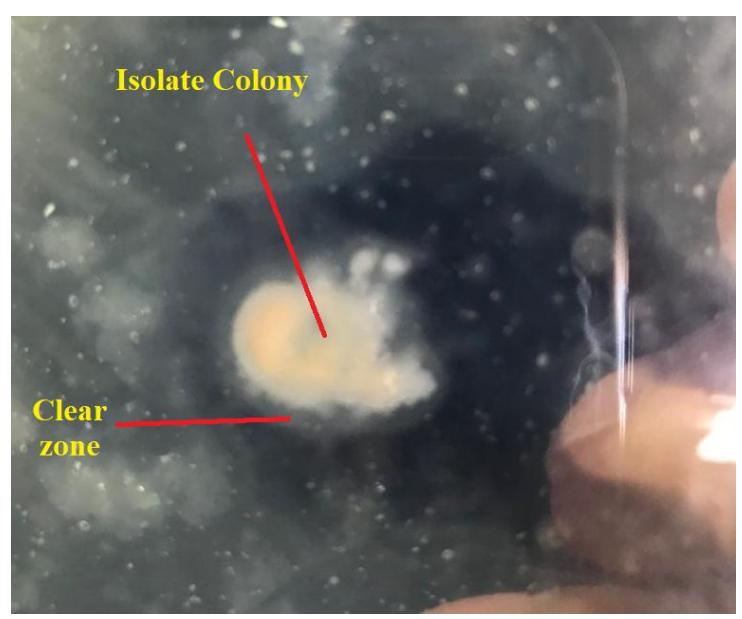

Figure 1. Amylase test showing clear zone on isolate-2. 
Screening for amylase activity showed all 6 isolates were positive in degrading amylum source. Positive results were shown by having clear zone around the colony (Figure 1.). On the other hand, blue color which appear on the media will indicate no results of any amylase activities. If any blue color was produced, this was caused by the amylum contained in the media that acted as a charge donor to polyiodide ions in the iodine solution as the charge acceptor (Madhu et al., 2016). By this reaction, they formed a Charge-Transfer (CT) Complex that when absorbed various wavelength of light would transform its color into characteristic dark blue (Saenger, 1984). However, if the bacteria possessed amylase enzymes, it would degrade the amylum (which is a polysaccharide) into its monomers, glucose (a monosaccharide). Glucose and polyiodide would not produce any CT complex which resulted in no color (clear zone) around the colony (Goedecke, 2016). From those 6 isolates, isolate- 6 displayed the biggest clear zone which indicate the highest amylase catalytic activity. Actinomycetes species known to have such catalytic activity of amylase enzyme predominantly belongs to the genus Streptomyces spp. (Kafilzadeh \& Dehdari, 2015; Swarna \& Gnanadoss, 2020a).

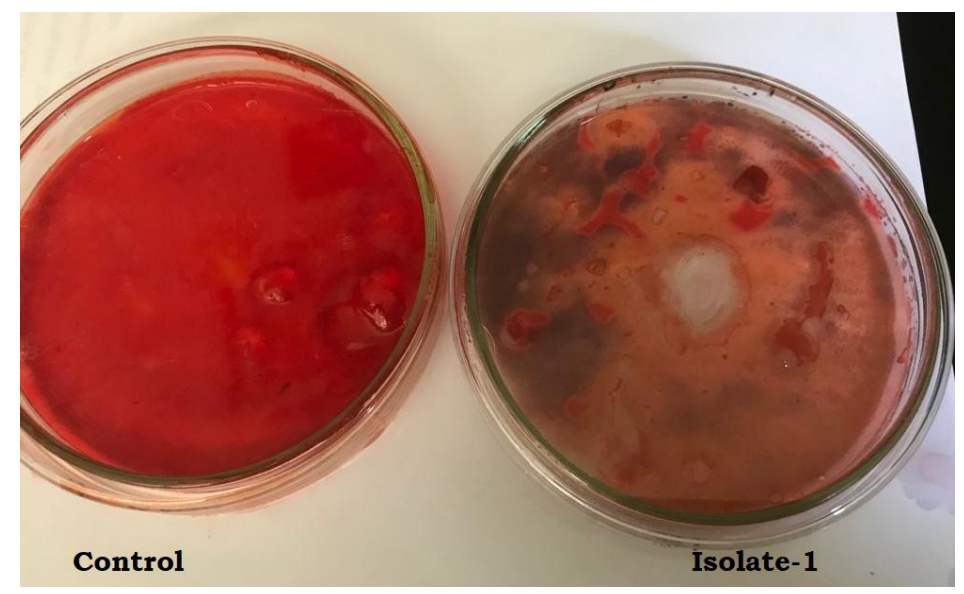

Figure 2. Cellulase test showing clear zone on isolate-1.

Cellulase activity was screened by pouring off $1 \%$ of Congo-red (CR) solution on the Actinomycetes-grown agar media for 15 minutes. The CR molecules would tightly bind to the cellulose polysaccharide through hydrogen bond formation between the amino functional groups of the $\mathrm{CR}$ and the hydroxyl group (-OH) of the cellulose polysaccharide (Carboxymethyl Cellulose) producing a dark reddish color 
(Yakupova et al., 2019). If it is not bind through such pattern, it would subsequently be removed easily if rinsed with $\mathrm{NaCl}$ solution, leaving a clear zone (Figure 2.). Degradation of cellulose by cellulase enzyme could hinder this bond that is used for cellulase catalytic activity identification (McDonald et al., 2012). Our result showed that only 5 isolates were capable of producing cellulase enzyme which were: isolate- 1 , isolate-2, isolate-3, isolate-4 and isolate-6. Other researches have also experienced the same result of cellulase producing-Actinomycetes isolated from Mangrove forest sediments and other marine ecosystems (Mohanta, 2014; Ratnakomala et al., 2019). Examples of such species are : Microbispora sp., Cellulomonas sp., Streptomyces spp. and Thermobifida sp. (Ventorino et al., 2016; Wilson, 1992).

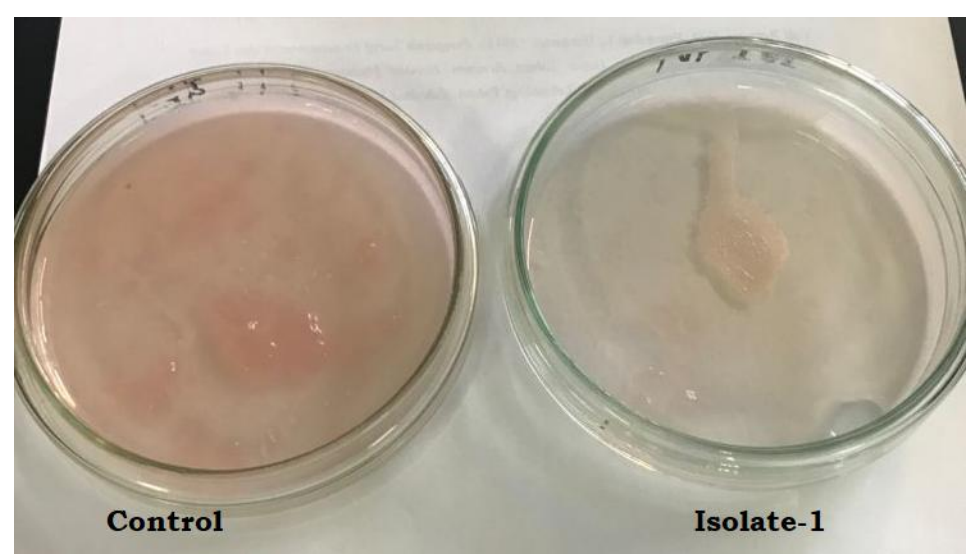

Figure 3. Lipase test showing colorless media and reddish colony of isolate- 1 .

The isolates were also screened for their ability to degrade lipid. When grown in ISP2 agar, the medium was also added with $1 \%$ of olive oil (as the source of lipid) and 0,01\% of Rhodamine-B as the indicator dye. All isolates tested positive for lipase enzyme. An example is shown on isolate-1 above (Figure 3). Under lipase catalytic activity, the fatty acids released from lipid hydrolysis would bind to Rhodamine-B (Jette \& Ziomek, 1994). This would then leave the media become more colorless and the colonies became more reddish in color because of the Rhodamine-B absorbed (Pramiadi \& Yulianti, 2014). Isolation and identification of Actinomycetes from Mangrove ecosystem in Bhitarkanika, India by Kishore (2011) has placed all of his lipase-producing Actinomycetes isolates in the genus of Streptomyces spp. 


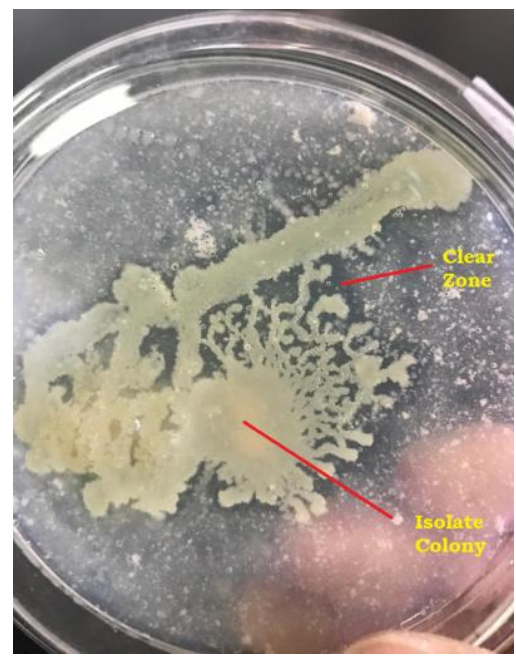

Figure 4. Protease test showing clear zone around isolate- 5 colony.

Protease activity was analyzed by seeing any clear zones formed by the catalytic reaction of protease enzymes that decompose protein contained in the media by using skimmed milk as the source (Perwendha et al., 2020). An example was shown on isolate-5 where clear zone was formed around the colony (Figure 4.). Similar to the previous researches mentioned above, Streptomyces spp. was also the most abundant species producing such enzyme that were isolated form Mangrove soils (Kandasamy \& Manivannan, 2007; Swarna \& Gnanadoss, 2020b). In our research, only 4 isolates displayed clear zone on protein-added media which were: isolate- 1 , isolate- 2 , isolate- 4 , and isolate- 5 .

Distribution of each isolate for all the hydrolytic exoenzymes could bee seen in Table 1. below.

Table 1. Distribution of Hydrolytic Exoenzymes in Each Isolates

\begin{tabular}{|c|c|c|c|c|c|c|}
\hline Enzyme & Isolate-1 & Isolate-2 & Isolate-3 & Isolate-4 & Isolate-5 & Isolate-6 \\
\hline Amylase & + & + & + & + & ++ & + \\
\hline Cellulase & + & + & + & + & - & + \\
\hline Protease & + & + & - & + & + & - \\
\hline Lipase & + & + & + & + & + & + \\
\hline
\end{tabular}


From the table above, it is clearly seen that 3 isolates namely isolate- 1 , isolate-2, and isolate-4 possess all four of the hydrolytic exoenzymes. Isolate- 3 only capable of showing amylase, cellulase, and lipase activity. While only showing catalytic activity for amylase, lipase and protease enzymes, isolate- 5 however, displayed the highest activity for its amylase enzyme shown by having the biggest clear zone (amylolytic zone). These results indicate that, further research on the effectivity of each exoenzymes produced is still imperative to be conducted. Effectivity analysis could be conducted by adding the crude enzyme extract on animal feed (possibly with a range of concentration) and either feed it directly to farm animals to observe its growth and development parameters (in vivo) or by analyzing the catalytic activity of each exoenzyme extract (in vitro) by measuring the amount or concentration of monomers produced during the degradation of raw materials of feed as its substrate. Genetic sequencing could also be performed to identify the species of each isolate couple with genetic mapping to locate specific genes mostly responsible for enzyme production.

\section{CONCLUSION \& RECOMMENDATION}

1. Marine Actinomycetes was successfully isolated from Mangrove forests of Oesapa beach, proving that local habitats of East Nusa Tenggara ecosystems could serves as alternative source for secondary metabolite producing Actinomycetes, especially hydrolytic exoenzymes.

2. These Marine Actinomycetes isolates from Mangrove sediments of Oesapa beach showed potential in producing hydrolytic exoenzymes that could be prospective in applying them as animal feed additive enzymes.

3. Further analysis should be performed on the catalytic activity of each hydrolytic exoenzymes produced by each isolate to compare its effectivity.

4. Further exploration should be conducted in other marine habitats for more diverse Actinomycetes isolates producing more various hydrolytic exoenzymes.

\section{REFERENCES}

Abay, U. (2020, December 25). Wujudkan Lumbung Ternak, Viktor Bungtilu Laiskodat Siap Dukung Transformasi Polbangnak di NTT. 
https://www.swadayaonline.com/artikel/8042/Wujudkan-Lumbung-Tern ak-Viktor-Bungtilu-Laiskodat-Siap-Dukung-Transformasi-Polbangnak-diNTT/

Aghamirian, M. R., \& Ghiasian, S. A. (2009). Isolation and Characterization of Medically Important Aerobic Actinomycetes in Soil of Iran (2006-2007). The Open Microbiology Journal, 3, 53-57. https://doi.org/ 10.2174/1874285800903010053

Alnahdi, H. S. (2012). Isolation and screening of extracellular proteases produced by new Isolated Bacillus sp. Journal of Applied Pharmaceutical Science. https://doi.org/10.7324/JAPS.2012.2915

Birolli, W. G., Lima, R. N., \& Porto, A. L. M. (2019). Applications of Marine-Derived Microorganisms and Their Enzymes in Biocatalysis and Biotransformation, the Underexplored Potentials. Frontiers in Microbiology, 10. https://doi.org/10.3389/fmicb.2019.01453

$B P S$

Provinsi

NTT.

(2020). https://ntt.bps.go.id/statictable/2020/12/16/800/luas-penggunaan-lah an-sawah-dan-lahan-kering-menurut-kabupaten-kota-hektar-2019.html

Dharma Rudiansyah Rahmawati, R. (2019). Eksplorasi Bakteri Selulolitik dari Tanah Hutan Mangrove Peniti, Kecamatan Segedong, Kabupaten Mempawah. Jurnal Protobiont, 6(3), Article 3. https:// doi.org/ 10.26418/protobiont.v6i3.22489

Goedecke, C. (2016). Why Does Iodine Turn Starch Blue? ChemViews. https://doi.org/10.1002/chemv.201600103

Gohel, H. R., Contractor, C. N., Ghosh, S. K., \& Braganza, V. J. (2014). A comparative study of various staining techniques for determination of extra cellular cellulase activity on Carboxy Methyl Cellulose (CMC) agar plates. 6.

Jette, J. F., \& Ziomek, E. (1994). Determination of lipase activity by a rhodamine-triglyceride-agarose assay. Analytical Biochemistry, 219(2), 256-260. https://doi.org/10.1006/abio.1994.1265

Joseph, J., Abirami, B., Manigundan, K., Gopikrishnan, V., \& Radhakrishnan, M. (2021). Chapter 9 - Antimicrobial peptides from Actinobacteria: Current status and future prospects. In S. Das \& H. R. Dash (Eds.), Microbial and Natural Macromolecules (pp. 205-231). Academic Press. https://doi.org/ 10.1016/B978-0-12-820084-1.00009-0

Kafilzadeh, F., \& Dehdari, F. (2015). Amylase activity of aquatic actinomycetes isolated from the sediments of mangrove forests in south of Iran. The Egyptian Journal of Aquatic Research, 41(2), 197-201. https://doi.org/10.1016/j.ejar.2015.04.003

Kandasamy, K., \& Manivannan, S. (2007). Production of Alkaline Protease by 
Streptomyces sp., Isolated from Coastal Mangrove Sediment. Research Journal of Environmental Sciences, 1, 173-178. https://doi.org/10.3923/rjes.2007.173.178

Kishore, P. (2011). Isolation, characterization and identification of Actinobacteria of Mangrove ecosystem, Bhitarkanika, Odisha [MSc]. http://ethesis.nitrk1.ac.in/2337/

Lehmann, C. (2001). Hydrolytic Enzymes: Amylases, Proteases, Lipases.

Lewokeda, A. (2020, November 27). NTT alokasikan Rp1,1 triliun setiap tahun untuk pengadaan pakan ternak. Antara News. https://www.antaranews.com/berita/1863792/ntt-alokasikan-rp11-triliu n-setiap-tahun-untuk-pengadaan-pakan-ternak

Luang-In, V., Yotchaisarn, M., Saengha, W., Udomwong, P., Deeseenthum, S., \& Maneewan, K. (2019). Isolation and Identification of Amylase-producing Bacteria from Soil in Nasinuan Community Forest, Maha Sarakham, Thailand. Biomedical and Pharmacology Journal, 12(3), 1061-1068.

Madhu, S., Evans, H. A., Doan-Nguyen, V. V. T., Labram, J. G., Wu, G., Chabinyc, M. L., Seshadri, R., \& Wudl, F. (2016). Infinite Polyiodide Chains in the Pyrroloperylene-Iodine Complex: Insights into the Starch-Iodine and Perylene-Iodine Complexes. Angewandte Chemie International Edition, 55(28), 8032-8035. https://doi.org/10.1002/anie.201601585

McDonald, J. E., Rooks, D. J., \& McCarthy, A. J. (2012). Chapter nineteen-Methods for the Isolation of Cellulose-Degrading Microorganisms. In H. J. Gilbert (Ed.), Methods in Enzymology (Vol. 510, pp. 349-374). Academic Press. https://doi.org/10.1016/B978-0-12-415931-0.00019-7

Mohanta, Y. K. (2014). Isolation of Cellulose-Degrading Actinomycetes and Evaluation of their Cellulolytic Potential. Bioengineering and Bioscience, 2(1), 1-5. https://doi.org/10.13189/bb.2014.020101

Ortenberg, E., \& Telsch, B. (2003). 42-Taste and odour problems in potable water. In D. Mara \& N. Horan (Eds.), Handbook of Water and Wastewater Microbiology (pp. 777-793). Academic Press. https://doi.org/10.1016/B978-012470100-7/50043-1

Perwendha, R., Oetari, A., \& Sjamsuridzal, W. (2020). Skimmed milk-degrading ability of Rhizopus azygosporus UICC 539 at various temperatures. 050006. https://doi.org/10.1063/5.0007872

Pramiadi, D., \& Yulianti, E. (2014). Isolasi dan uji aktivitas enzim lipase termostabil dari bakteri termofilik pasca erupsi Merapi. 11.

Ratnakomala, S., Fahrurrozi, \& Yopi. (2019). Enhancement of Cellulase (CMCase) production from marine actinomycetes Streptomyces sp. Bse 7-9: Optimization of fermentation medium by Response Surface Methodology. 
IOP Conference Series: Earth and Environmental Science, 251, 012005. https://doi.org/10.1088/1755-1315/251/1/012005

Saenger, W. (1984). The structure of the blue starch-iodine complex| SpringerLink. Naturwissenschaften, 71, 31-36.

Singh, P. (2015). Animal Feed Additive.

Sutomo, S. (2016). Asal Usul Formasi Savana: Tinjauan dari Nusa Tenggara Timur dan Hasil Penelitian di Baluran Jawa Timur [Origin of savanna formation: Literature review from East Nusa Tenggara and research results from Baluran East Java Indonesia]. 20.

Swarna, D., \& Gnanadoss, J. J. (2020a). Screening and Molecular Characterization of Actinomycetes from Mangrove Soil Producing Industrially Important Enzymes. Journal of Scientific Research, 64(02), 87-95. https://doi.org/10.37398/JSR.2020.640211

Swarna, D., \& Gnanadoss, J. J. (2020b). Screening and Molecular Characterization of Actinomycetes from Mangrove Soil Producing Industrially Important Enzymes. Journal of Scientific Research, 64(02), 87-95. https://doi.org/10.37398/JSR.2020.640211

Vaijayanthi, G., Vijayakumar, R., \& Dhanasekaran, D. (2016). Actinobacteria-A Biofactory of Novel Enzymes. In Actinobacteria-Basics and Biotechnological Applications. IntechOpen. https://doi.org/10.5772/61436

Velázquez-De Lucio, B. S., Hernández-Domínguez, E. M., Villa-García, M., Diaz-Godinez, G., Mandujano-Gonzalez, V., Mendoza-Mendoza, B., \& Álvarez-Cervantes, J. (2021). Exogenous Enzymes as Zootechnical Additives in Animal Feed: A Review. Catalysts, 11(7), 851. https://doi.org/10.3390/catal11070851

Ventorino, V., Ionata, E., Birolo, L., Montella, S., Marcolongo, L., de Chiaro, A., Espresso, F., Faraco, V., \& Pepe, O. (2016). Lignocellulose-Adapted Endo-Cellulase Producing Streptomyces Strains for Bioconversion of Cellulose-Based Materials. Frontiers in Microbiology, 7, 2061. https://doi.org/10.3389/fmicb.2016.02061

Watts, S. A., Lawrence, A. L., \& Lawrence, J. M. (2020). Chapter 10-Nutrition. In J. M. Lawrence (Ed.), Developments in Aquaculture and Fisheries Science (Vol. 43, pp. 191-208). Elsevier. https://doi.org/10.1016/B978-0-12-819570-3.00010-X

Wilson, D. B. (1992). Biochemistry and Genetics of Actinomycete Cellulases. Critical Reviews in Biotechnology, 12(1-2), 45-63. https://doi.org/10.3109/07388559209069187

Yakupova, E. I., Bobyleva, L. G., Vikhlyantsev, I. M., \& Bobylev, A. G. (2019). Congo Red and amyloids: History and relationship. Bioscience Reports, 39(1), BSR20181415. https://doi.org/10.1042/BSR20181415 